\title{
Photochemical efficiency in cladodes of 'Gigante' cactus pear cultivated under different spacings and organic fertilization
}

\author{
Cleiton F. B. Brito ${ }^{1}$, Sérgio L. R. Donato ${ }^{2}$, Alessandro de M. Arantes ${ }^{2}$, Paulo E. R. Donato ${ }^{2}$ \& João A. da Silva ${ }^{2}$ \\ ${ }^{1}$ Universidade Estadual de Montes Claros/Departamento de Ciências Agrárias. Janaúba, MG. E-mail: cleiton.ibce@hotmail.com (Corresponding author) \\ - ORCID: 0000-0001-9423-4980 \\ ${ }^{2}$ Instituto Federal de Educação, Ciência e Tecnologia Baiano. Guanambi, BA. E-mail: sergio.donato@ifbaiano.edu.br - ORCID: 0000-0002-7719-466; \\ alessando.arantes@ifbaiano.edu.br - ORCID: 0000-0002-7520-9891; paulo.donato@ifbaiano.edu.br - ORCID: 0000-0001-8696-8378; joao.silva@ifbaiano.edu.br - \\ ORCID: 0000-0001-5358-356X
}

\section{Key words:}

Opuntia

arrangement of plants

chlorophyll fluorescence

\begin{abstract}
A B S T R A C T
The objective of this study was to determine the photochemical efficiency of 'Gigante' cactus pear cultivated under different spacings and bovine manure doses in the semi-arid region. The experiment was conducted in a randomized block design in a $4 \times 3 \times 7$ factorial scheme, with three replicates. The first factor consisted of four doses of organic fertilization $\left(0,30,60\right.$ and $90 \mathrm{Mg} \mathrm{ha}^{-1}$ year $^{-1}$ of bovine manure), the second one, of three spacings $(1.0 \mathrm{x}$ $0.5,2.0 \times 0.25$ and $3.0 \times 1.0 \times 0.25 \mathrm{~m})$ and the third one of seven reading times $(6,8,10,12$, 14,16 and $18 \mathrm{~h}$ ). Chlorophyll a fluorescence readings were taken in cactus pear cladodes in the dry and rainy seasons using a pulse-modulated fluorometer. Cladodes of 'Gigante' cactus pear cultivated under different spacings and bovine manure doses undergo changes in photosystem II during the dry season under the physiographic conditions of the semiarid region in Bahia. During the rainy season in the semi-arid region, the photosynthetic yield in cactus pear cladodes is considered ideal.
\end{abstract}

\section{Palavras-chave: \\ Opuntia \\ arranjo de plantas \\ fluorescência da clorofila}

\section{Eficiência fotoquímica em cladódios de palma forrageira 'Gigante' cultivada sob diferentes espaçamentos e adubação orgânica}

\begin{abstract}
R E S U M O
Objetivou-se determinar a eficiência fotoquímica da palma forrageira 'Gigante' cultivada sob diferentes espaçamentos e doses de esterco bovino na região semiárida. $\mathrm{O}$ experimento foi conduzido em blocos ao acaso em esquema fatorial $4 \times 3 \times 7$, com três repetições. O primeiro fator foi constituído de quatro doses de adubação orgânica (0; 30; 60 e $90 \mathrm{Mg} \mathrm{ha}^{-1}$ ano $^{-1}$ de esterco bovino), o segundo, por três espaçamentos ( $1,0 \times 0,5 ; 2,0$ × 0,25 e 3,0 x 1,0 x 0,25 m) e o terceiro por sete horários de leitura $(6 ; 8 ; 10 ; 12 ; 14 ; 16$ e 18 h). Foram realizadas leituras de fluorescência da clorofila a em cladódios de palma forrageira nas épocas seca e chuvosa com auxílio de um fluorômetro de luz modulada. Os cladódios de palma forrageira 'Gigante' cultivada sob diferentes espaçamentos e doses de esterco bovino sofrem alterações no fotossistema II na época seca nas condições fisiográficas do semiárido baiano. Na época de chuvas na região semiárida o rendimento fotossintético em cladódios de palma forrageira é considerado ideal.
\end{abstract}




\section{INTRODUCTION}

Cactus pear (Opuntia ficus-indica) is used as animal feed in production systems of various arid and semi-arid regions worldwide (Grünwaldt et al., 2015), for having features of coexistence with the environmental limitations present in these regions, such as stress by water deficit, high temperatures and excess radiation (Donato et al., 2014).

Cactus pear is a xerophile plant and its physiology is characterized by the photosynthetic process called Crassulacean acid metabolism (CAM) and, under stress conditions, water is saved due to stomatal closure during the day and opening during the night with $\mathrm{CO}_{2}$ fixation. Thus, integration of production factors such as plant spacing and fertilization, within the soil-plant-atmosphere system, may have effect on plant physiological characteristics.

Plant spacing in the crop can affect light interception and photosynthetic efficiency (Cavalcante et al., 2014), because the larger total area of exposure to sunlight indicates higher production potential (Larcher, 2000; Taiz et al., 2017). Additionally, greater availability of nutrients in the soil may alter the expression of morphometric attributes and affect crop yield (Donato et al., 2014).

Chlorophyll $a$ fluorescence has allowed inferences on the efficiency of the photochemical phase of photosynthesis and can be useful in studies on the physiological behavior of CAM plants (Romo-Campos et al., 2013; Cruz et al., 2014; Díez et al., 2017). Thus, it can help understand the adaptability and resistance to drought of cactus pear in the soil-plantatmosphere production context of the semi-arid region. In addition, extrapolating these results may support the search for optimization of management practices. Conversely, studies on physiology are still scarce (Adams Terceiro et al., 1989; Winter \& Lesch, 1992; Becerril \& Valdivia, 2006) and are necessary to fill these gaps in the knowledge on the crop.

Therefore, the objective was to determine the photochemical efficiency of 'Gigante' cactus pear cultivated under different spacings and bovine manure doses in the semi-arid region.

\section{Material ANd Methods}

The experiment was installed at the Federal Institute of Bahia, Campus of Guanambi, Bahia, Brazil (14 13' 33”' S; 42

46' 53" W; $525 \mathrm{~m}$ ), under mean annual rainfall of $680 \mathrm{~mm}$ and mean annual temperature of $26^{\circ} \mathrm{C}$. Cactus pear (Opuntia ficus indica Mill.), variety 'Gigante', was planted in September 2009 before the rainy season, in typic dystrophic Red Yellow Latosol, with weak A horizon, medium texture, under hypoxerophilic Caatinga, on flat to gently undulating relief.

Maximum and minimum temperatures, rainfall, relative air humidity and wind speed recorded along the experimental period are presented in Figure 1.

The experimental design was randomized blocks in $4 \mathrm{x}$ $3 \times 7$ factorial scheme, with three replicates. The first factor consisted of four doses of organic fertilization $(0 ; 30 ; 60$ and $90 \mathrm{Mg} \mathrm{ha}^{-1}$ year $^{-1}$ of bovine manure), the second one, of three spacings $(1.0 \times 0.5 ; 2.0 \times 0.25$ and $3.0 \times 1.0 \times 0.25 \mathrm{~m})$ and the third one, of seven reading times $(6 ; 8 ; 10 ; 12 ; 14 ; 16$ and $18 \mathrm{~h})$. The total area was $2,304 \mathrm{~m}^{2}$, whereas plot area was $64 \mathrm{~m}^{2}(16 \mathrm{x}$ $4 \mathrm{~m})$ and evaluations were made in a $16 \mathrm{~m}^{2}$ area $(8 \times 2 \mathrm{~m})$. The same population of 20,000 plants $\mathrm{ha}^{-1}$ was maintained in the planting spacings used.

Before soil tillage, samples were collected in the $0-20 \mathrm{~cm}$ layer for chemical and textural analyses (Table 1), carried out at the Soil Analysis Laboratory of the State University

Table 1. Mean chemical characteristics of the soil relative to the experimental area occupied by blocks 1, 2 and 3

\begin{tabular}{lcrrr}
\hline Parameters & Unit & Block1 & Block 2 & Block 3 \\
$\mathrm{pH}$ & - & 5.60 & 5.33 & 5.33 \\
$\mathrm{P}$ & $\mathrm{mg} \mathrm{dm}^{-3}$ & 27.25 & 10.75 & 11.00 \\
$\mathrm{~K}^{+}$ & $\mathrm{cmol}_{\mathrm{c}} \mathrm{dm}^{-3}$ & 0.28 & 0.27 & 0.31 \\
$\mathrm{Ca}^{2+}$ & $\mathrm{cmolc}_{\mathrm{c}} \mathrm{dm}^{-3}$ & 2.44 & 1.93 & 1.68 \\
$\mathrm{Mg}^{2+}$ & $\mathrm{cmol}_{\mathrm{c}} \mathrm{dm}^{-3}$ & 0.89 & 0.92 & 0.88 \\
$\mathrm{Al}^{3+}$ & $\mathrm{cmol}_{\mathrm{c}} \mathrm{dm}^{-3}$ & 0.11 & 0.19 & 0.17 \\
$\mathrm{H}^{+}$ & $\mathrm{cmol}_{\mathrm{c}} \mathrm{dm}^{-3}$ & 1.69 & 1.67 & 1.71 \\
$\mathrm{Na}^{+}$ & $\mathrm{cmol}_{\mathrm{c}} \mathrm{dm}^{-3}$ & 0.00 & 0.07 & 0.06 \\
$\mathrm{SB}$ & $\mathrm{cmol}_{\mathrm{c}} \mathrm{dm}^{-3}$ & 3.62 & 3.13 & 2.88 \\
$\mathrm{t}$ & $\mathrm{cmol}_{\mathrm{c}} \mathrm{dm}^{-3}$ & 3.73 & 3.32 & 3.04 \\
$\mathrm{~T}$ & $\mathrm{cmol}_{\mathrm{c}} \mathrm{dm}^{-3}$ & 5.42 & 4.98 & 4.75 \\
$\mathrm{~V}$ & $\%$ & 66.58 & 62.42 & 60.42 \\
$\mathrm{~m}$ & $\%$ & 3.08 & 6.08 & 5.42 \\
$\mathrm{ESP}$ & $\%$ & 0.00 & 1.00 & 1.00 \\
$\mathrm{OM}$ & $\mathrm{g} \mathrm{dm}^{-3}$ & 16.17 & 14.42 & 13.42 \\
$\mathrm{Cu}$ & & 0.38 & 0.38 & 0.33 \\
$\mathrm{Mn}^{++}$ & $\mathrm{mg} \mathrm{dm}^{-3}$ & 15.38 & 18.46 & 19.00 \\
$\mathrm{Zn}^{++}$ & $\mathrm{mg} \mathrm{dm}^{-3}$ & 2.02 & 1.21 & 1.03 \\
& $\mathrm{mg} \mathrm{dm}$ & & Sandy clay loam & \\
\hline
\end{tabular}

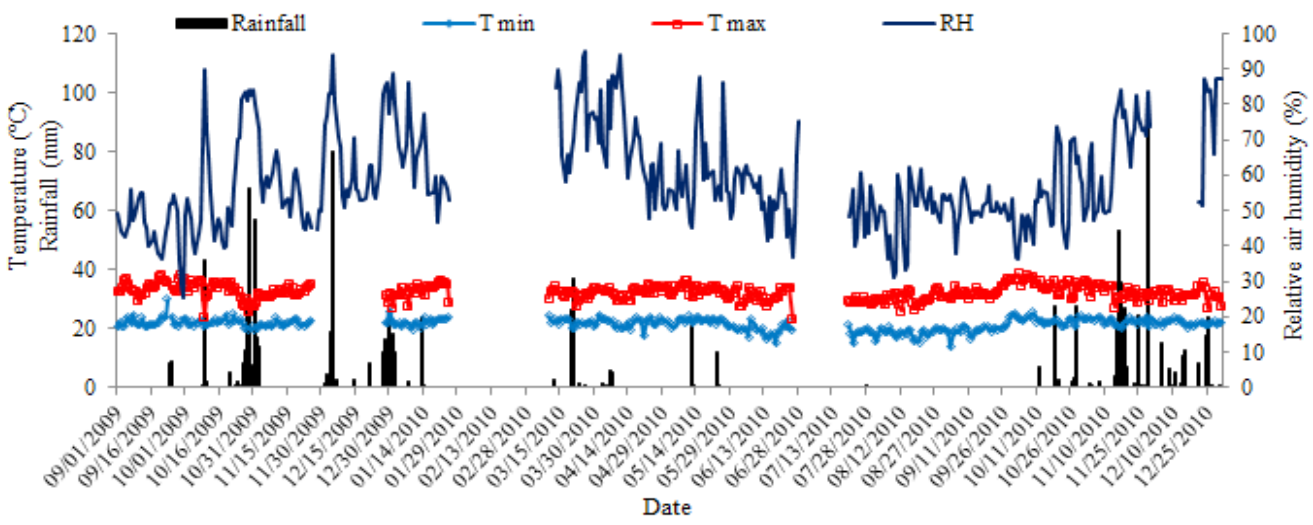

Note: data collected at the automatic meteorological station installed in the experimental area of the Federal Baiano Institute.

Figure 1. Temperature (maximum-Tmax and minimum-Tmin), rainfall and relative air humidity (RH) along the experimental period 
of Southwestern Bahia, Campus of Vitória da Conquista, according to EMBRAPA (1997).

The area was subsoiled, plowed, harrowed and then furrowed at the planting spacings. Organic fertilizer was applied in the planting furrow according to the preestablished doses of fresh manure, at once, and repeated after one year in the other growth season. Bovine manure was incorporated to the soil using the furrower and the furrows were open again to plant the pads. The bovine manure showed the following composition: Organic matter $=63.73 \mathrm{~g} \mathrm{~kg}^{-1}, \mathrm{Ash}=36.27 \mathrm{dag} \mathrm{kg}^{-1}$, Total carbon $=29.98$ dag $\mathrm{kg}^{-1}$ and $\mathrm{pH}=7.42$, analyzed by the official method of the Ministry of Agriculture, Livestock and Food Supply (MAPA) (Brasil, 2007); Moisture content (dry basis) at $65^{\circ} \mathrm{C}=16.72 \%$; Macronutrients: $\mathrm{Ca}, \mathrm{Mg}, \mathrm{K}, \mathrm{N}$ and $\mathrm{S}=1.7 ; 0.2 ; 2.5 ; 5.2$ and 2.3 $\mathrm{g} \mathrm{kg}^{-1}$ (EPA 3051/APHA 3120B), respectively; $\mathrm{P}=4.7 \mathrm{~g} \mathrm{~kg}^{-1}$ (APHA 4500-PC); Micronutrients (EPA 3051/APHA 3120B): B, $\mathrm{Cu}, \mathrm{Zn}, \mathrm{Mn}$ and $\mathrm{Fe}=2.1 ; 45.2 ; 200.5 ; 391.8$ and $1,932.4 \mathrm{mg} \mathrm{kg}^{-1}$, respectively; and Density $=0.38 \mathrm{~g} \mathrm{~cm}^{-3}$.

To install the experiment, mature cladodes with accumulation of reserves were selected from one single 15-yearold cactus pear plantation which had not been harvested for two years. After harvest, they remained in the shade for 15 days to cure, and then were planted. The cladodes were planted with the longest dimension in the East/West direction, buried about $50 \%$ in the soil for better fixation. Invasive plants were controlled using a hoe, two weedings and herbicide, two applications of glyphosate at dose of $200 \mathrm{~mL}$ of the commercial product $20 \mathrm{~L}^{-1}$ of water during the rainy seasons.

At 11 months after planting in July-August 2010 (dry season) and at 18 months in December 2010 - January 2011 (rainy season), chlorophyll $a$ fluorescence readings were taken in the cactus pear cladodes along the day. Seven readings were taken at $2 \mathrm{~h}$ intervals, from 6 to $18 \mathrm{~h}$, in three plants of the evaluation area.
Chlorophyll $a$ fluorescence readings were taken using a pulse-modulated fluorometer (OS1-FL - OPTI-Sciences). The clips to measure chlorophyll $a$ fluorescence were placed in the middle third of the cladode and the measurement was taken after 5 min of dark adaptation, by applying a 0.3 -s saturating light pulse. Initial fluorescence (Fo), maximum fluorescence $(\mathrm{Fm})$, variable fluorescence $(\mathrm{Fv})$ and photochemical efficiency (Fv/Fm) were evaluated at $0.6 \mathrm{kHz}$ frequency. During the measurements, a clip was used to adapt chloroplasts to the dark so that all photosystem II (PSII) reaction centers were open and the heat loss was minimum, as claimed by Strauss et al. (2006).

Additionally, readings were taken in light-adapted cladodes, by applying saturating pulses to determine chlorophyll fluorescence at the stationary state (Fs), maximum fluorescence in the light (Fms), variable fluorescence in the light (Fvs) and quantum yield of photosystem II (Yield). Three readings of dark and one of light were taken in each plant identified.

Data were subjected to analysis of variance and regression. Regression equation fits were based on the adequacy of the model to the studied phenomenon, significance of regression parameters by $\mathrm{t}$-test at 0.05 probability level and on the adjusted coefficient of determination $\left(\mathrm{R}^{2}\right)$. Means of the variables were grouped by the Scott-Knott criterion $(\mathrm{p}<0.05)$.

\section{Results AND Discussion}

The parameters of chlorophyll $a$ fluorescence evaluated in cladodes of 'Gigante' cactus pear during July-August, dry season, varied according to the reading times, regardless of spacing and organic fertilization (Table 2), except for maximum fluorescence $(\mathrm{Fm})$, variable fluorescence $(\mathrm{Fv})$ and quantum efficiency (Fv/Fm). Likewise, the parameters of chlorophyll $a$ fluorescence evaluated during December-January, rainy season in the region, varied according to the reading times, regardless

Table 2. Initial fluorescence (Fo), maximum fluorescence (Fm), variable fluorescence (Fv), quantum efficiency (Fv/Fm), chlorophyll a fluorescence at the stationary state (Fs), maximum fluorescence in the light (Fms), variable fluorescence in the light (Fvs) and quantum yield of photosystem II (Yield) in 'Gigante' cactus pear along the months of July-August (dry season)

\begin{tabular}{ccccccccc}
\hline Time (h) & Fo & Fm & Fv & Fv/Fm & Fs & Fms & Fvs & Yield \\
6 & $191.0 \mathrm{C}$ & 750.2 & 559.4 & 0.70 & $321.8 \mathrm{D}$ & $1060.4 \mathrm{~B}$ & $738.8 \mathrm{~A}$ & $0.63 \mathrm{~A}$ \\
8 & $222.2 \mathrm{~A}$ & 783.5 & 561.5 & 0.67 & $435.6 \mathrm{~A}$ & $1274.5 \mathrm{~A}$ & $839.1 \mathrm{~A}$ & $0.61 \mathrm{~A}$ \\
10 & $216.4 \mathrm{~A}$ & 683.7 & 467.5 & 0.65 & $395.5 \mathrm{~B}$ & $1015.6 \mathrm{~B}$ & $620.2 \mathrm{~B}$ & $0.55 \mathrm{~B}$ \\
12 & $201.5 \mathrm{~B}$ & 663.4 & 462.1 & 0.65 & $356.7 \mathrm{C}$ & $927.0 \mathrm{~B}$ & $570.5 \mathrm{~B}$ & $0.52 \mathrm{~B}$ \\
14 & $204.5 \mathrm{~B}$ & 689.1 & 484.8 & 0.63 & $370.4 \mathrm{C}$ & $926.2 \mathrm{~B}$ & $556.1 \mathrm{~B}$ & $0.58 \mathrm{~B}$ \\
16 & $202.9 \mathrm{~B}$ & 697.7 & 495.2 & 0.67 & $377.9 \mathrm{C}$ & $1019.1 \mathrm{~B}$ & $641.3 \mathrm{~B}$ & $0.58 \mathrm{~B}$ \\
18 & $190.1 \mathrm{C}$ & 664.5 & 474.6 & 0.67 & $358.2 \mathrm{C}$ & $1196.5 \mathrm{~A}$ & $838.4 \mathrm{~A}$ & $0.63 \mathrm{~A}$ \\
CV $(\%)$ & 10.2 & 27.0 & 36.0 & 12.8 & 13.7 & 32.9 & 45.8 & 17.9 \\
\hline
\end{tabular}

Means followed by the same letter in the columns belong to the same group by the Scott-Knott criterion at 0.05 probability level

Table 3. Initial fluorescence (Fo), maximum fluorescence (Fm), variable fluorescence (Fv), quantum efficiency (Fv/Fm), chlorophyll a fluorescence at the stationary state (Fs), maximum fluorescence in the light (Fms), variable fluorescence in the light (Fvs) and quantum yield of photosystem II (Yield) in 'Gigante' cactus pear along the months of December-January (rainy season)

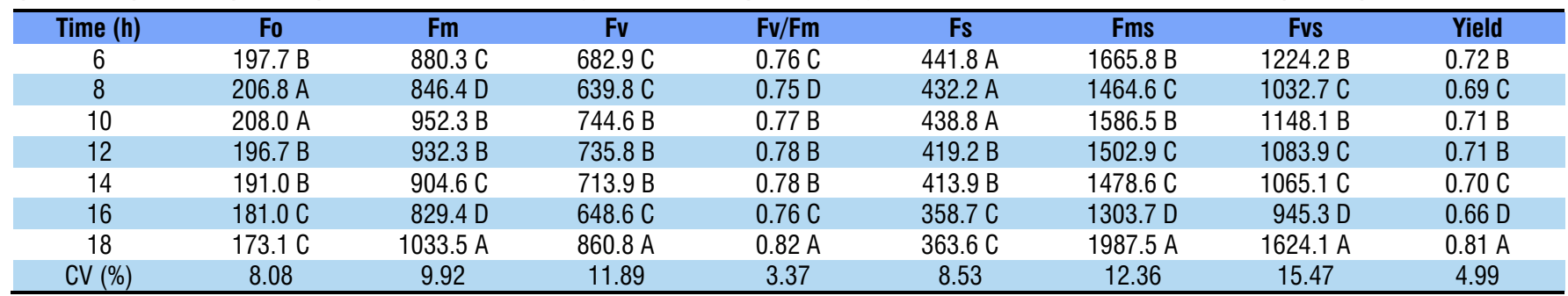

Means followed by the same letter in the columns belong to the same group by the Scott-Knott criterion at 0.05 probability level 
of spacing and organic fertilization (Table 2); however, Fv/Fm ratio and quantum yield (Yield) varied according to spacing and organic fertilization, regardless of reading time.

Among the fluorescence parameters, Fv/Fm and yield are considered as the most relevant because they indicate the functioning of photosystem II (PSII) and, consequently, the efficiency in the use of photochemical radiation in carbon assimilation by plants.

The mean value of Fv/Fm ratio during the day, 0.660 in the dry season, indicates that the photosynthetic apparatus of the cladodes was altered, because this value is not within the range considered as optimal $(\mathrm{Fv} / \mathrm{Fm}=0.800 \pm 0.5)$ by Bolhàr-Nordenkampf et al. (1989). Such alteration is probably due to the fact that the quantity of photochemical energy introduced in the cladode is higher than its capacity of using it for photosynthesis, resulting in decline of Fv/Fm, which characterizes a higher non-photochemical dissipation and indicates that these cladodes are acting with the CAM physiological mechanism.

Regarding the Yield, two groups were formed, in which the highest values were found at the coolest hours of the day (6, 8 and $18 \mathrm{~h}$ ), the times corresponding to phases I and IV of the CAM photosynthesis (Nobel, 2001), respectively. These values and the Fv/Fm indicate that cactus pear cladodes under the conditions prevailing in the dry season of the semi-arid region exhibit a damaged photosynthetic apparatus and in a more accentuated way at the times of highest stress by heat and radiation, between 10 and $16 \mathrm{~h}$.

Modifications in chlorophyll $a$ fluorescence, under stress conditions, occur when enzymes responsible for carbon reduction are damaged and the electron transport is inhibited, which suggests there is a reduction in the amount of energy used by the plant for photochemical processes, as observed in Opuntia jaliscana under dry climate and low humidity conditions (Romo-Campos et al., 2013). In addition, under conditions of drought, heat stress and radiation, the chlorenchyma loses significant amount of water and the cladode begins to exhibit rough aspect and loss of its characteristic green color (Becerril \& Valdivia, 2006), indicating loss of chlorophyll (Pimienta-Barrios et al., 2005). These descriptions corroborate with the results of fluorescence found in the present study for the dry season.

There was interaction $(\mathrm{p}<0.05)$ between planting spacings and bovine manure doses (Figure 2). Fv/Fm and Yield data fitted to cubic models at the spacings E1 $(1.0 \times 0.5 \mathrm{~m})$ and E3 $(3.0 \times 1.0 \times 0.25 \mathrm{~m})$ and to a quadratic model at E2 $(2.0 \mathrm{x}$ $0.25 \mathrm{~m}$ ). The cubic models fitted are possibly justified by the physiological adaptation of the cactus pear cladodes to the interaction in the environment between the availability of nutrients due to organic fertilizations and the planting spacings (E1 and E3).

At the spacing $2.0 \times 0.25 \mathrm{~m}$, there is less shading and the cladodes, under no bovine manure application, show the highest value of Fv/Fm. Fertilization with organic matter induces plant growth, promoting the appearance of new cladodes, which may justify the decline in Fv/Fm and Yield at doses of 30 and $60 \mathrm{Mg} \mathrm{ha}^{-1}$ year $^{-1}$, and the subsequent increase of the values at the dose of $90 \mathrm{Mg} \mathrm{ha}^{-1}$ year $^{-1}$, because when the manure was not applied the plant did not grow. Therefore, it had cladodes with more reserves and higher resistance to the predominant conditions in the environment. Nonetheless, due to the effect of organic fertilization, new cladodes grew, which undergo more damage to the photosynthetic apparatus under drought conditions, resulting in reduction of efficiency and quantum yield. Daughter cladodes represent strong sink organs and cause physiological stress on mother cladodes during the dry season (Zañudo-Hernández et al., 2010), with reduction in the daily $\mathrm{C}$ gain and relative water content in mother cladodes, suggesting water movement from mother to daughter (Pimienta-Barrios et al., 2005). In addition, $\mathrm{CO}_{2}$ assimilation is more affected in the phase IV of CAM (Nobel, 2001) (net $\mathrm{CO}_{2}$ absorption in late afternoon) by the combined effects of daughter cladodes and drought.

Similar response may have occurred for the spacings E1 $(1.0 \times 0.5 \mathrm{~m})$ and E3 $(3.0 \times 1.0 \times 0.25 \mathrm{~m})$, but they showed greater plant distribution uniformity, with greater exploration of the soil by the root system and less shading between neighboring plants, which favors photosynthetic efficiency
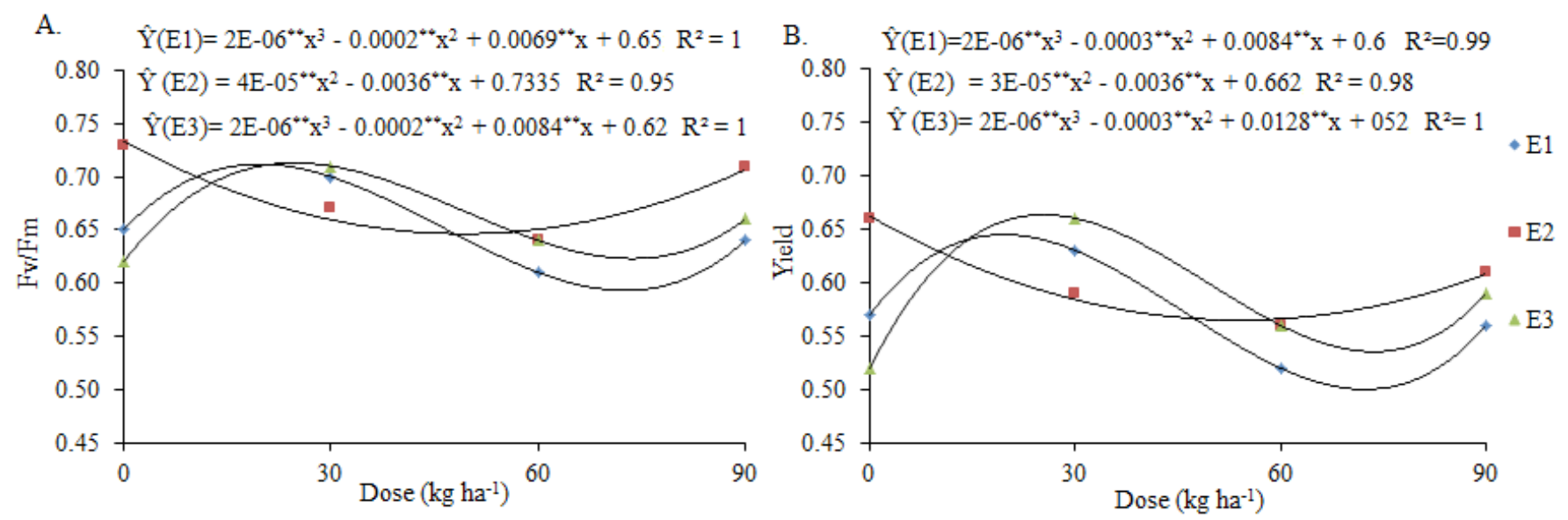

$\mathrm{E} 1=1.0 \times 0.5 ; \mathrm{E} 2=2.0 \times 0.25$ and $\mathrm{E} 3=3.0 \times 1.0 \times 0.25 \mathrm{~m}$

Figure 2. Quantum efficiency (Fv/Fm) (A) and quantum yield of photosystem II (Yield) (B) in 'Gigante' cactus pear cultivated at different spacings and bovine manure doses during July-August (dry season) 
and, consequently, higher growth (Silva et al., 2016). With the application of $30 \mathrm{Mg} \mathrm{ha}^{-1}$ year $^{-1}$, there was a higher growth rate, resulting in higher $\mathrm{Fv} / \mathrm{Fm}$ and Yield, followed by a reduction at $60 \mathrm{Mg} \mathrm{ha}^{-1}$ year $^{-1}$ and a subsequent increase at $90 \mathrm{Mg} \mathrm{ha}^{-1}$ year $^{-1}$, and the data fitted to cubic models, with adequate coefficients of determination.

The higher quantum yield observed in the rainy season (January-February), compared with the dry season (JulyAugust), was possibly due to the increase of $C$ gain in response to the availability of water from the rainfalls, associated with lower temperatures and high relative air humidity (Figure 1). This promotes $\mathrm{CO}_{2}$ capture during the night (via CAM) and during the day (via C3) (Pimienta-Barrios et al., 2012); consequently, $\mathrm{Fv} / \mathrm{Fm}$ and Yield values are within the range considered as optimal, which evidences adequate functioning of the electron transport chain.

The reduction in PSII efficiency in the dry season, compared with the rainy season, confirms the negative influence of water deficit, as described by Masrahi et al. (2012) and PimientaBarrios et al. (2012), under arid conditions. It is important to highlight also the relevance of organic fertilization because, in general, photochemical efficiency $(\mathrm{Fv} / \mathrm{Fm})$ increases with greater supply of nutrients (Cuzzuol et al., 2016).

The results of ideal quantum efficiency in cactus pear cladodes in the rainy season are possibly due to the fact that instantaneous $\mathrm{CO}_{2}$ assimilation and daily $\mathrm{C}$ gain of the cladodes significantly increased after plants received a substantial volume of rain. Studies on cactus pear cladodes have found that the net daily $\mathrm{CO}_{2}$ capture was more accentuated in rainy periods and root formation increased in response to the availability of water in the soil (PimientaBarrios et al., 2012).

The results of the present study confirm that the chlorophyll a fluorescence measurement is a good tool to evaluate the efficient use of radiation in cactus pear (Franck et al., 2013).

\section{Conclusions}

1. Cladodes of 'Gigante' cactus pear cultivated under different spacings and bovine manure doses undergo alterations in the photosystem II in the dry season under the physiographic conditions of the semi-arid region of Bahia.

2. In the rainy season in the semi-arid region, the photosynthetic yield in cactus pear cladodes is considered ideal.

\section{Literature Cited}

Adams Terceiro, W. W.; Díaz, M.; Winter, K. Diurnal changes in photochemical efficiency, the reduction state of $\mathrm{Q}$, radiation less energy dissipation, and non-photochemical fluorescence quenching in cacti exposed to natural sunlight in northern Venezuela. Oecologia, v.80, p.553-561, 1989. https://doi. org/10.1007/BF00380081

Becerril, G. A.; Valdivia, C. B. P. Alteraciones fisiológicas provocadas por sequía en nopal (Opuntia ficus-indica). Revista Fitotecnia Mexicana, v.29, p.231-237, 2006.
Bolhàr-Nordenkampf, H. R.; Long, S. P.; Baker, N. R.; Oquist, G.; Schreiber, U.; Lechner, E. G. Chlorophyll fluorescence as a probe of the photosynthetic competence of leaves in the field: A review of current instrumentation. Functional Ecology, v.3, p.497-514, 1989. https://doi.org/10.2307/2389624

Brasil. Ministério da Agricultura, Pecuária e Abastecimento. Secretaria de Defesa Agropecuária. Instrução Normativa SDA no 28, de 27 de julho de 2007. Aprova os Métodos Analíticos Oficiais para Fertilizantes Minerais, Orgânicos, Organo Minerais e Corretivos, disponíveis na Coordenação Geral de Apoio Laboratorial CGAL/ SDA/MAPA, na Biblioteca Nacional de Agricultura BINAGRI e no sítio do Ministério da Agricultura, Pecuária e Abastecimento. Brasília: Diário Oficial da República Federativa do Brasil, 2007. Seção 1.

Cavalcante, L. A. D.; Santos, G. R. de A.; Silva, L. M. da; Fagundes, J. L.; Silva, M. A. da; Respostas de genótipos de palma forrageira a diferentes densidades de cultivo. Pesquisa Agropecuária Tropical, v.44, p.424-433, 2014. https://doi.org/10.1590/S198340632014000400010

Cruz, L. I. B.; Cruz, M. do C. M.; Ferreira, E. A.; Castro, G. D. M. de; Almeida, M. de O. Eficiência quântica do fotossistema II de mudas de abacaxizeiro 'imperial' em resposta a associação com Piriformospora indica e herbicidas. Revista Brasileira de Fruticultura, v.36, p.794-804, 2014. https://doi.org/10.1590/01002945-411/13

Cuzzuol, G. R. F.; Canal, E. C.; Gama, V. N.; Zanetti, L. V. Relações do N, P e K com a fluorescência da clorofila, teores de nutrientes foliares e carboidratos solúveis do caule de Caesalpinia echinata Lam. Hoehnea, v.43, p.151-158, 2016. https://doi. org/10.1590/2236-8906-43/2015

Díez, M. C.; Moreno, F.; Gantiva, E. Effects of light intensity on the morphology and CAM photosynthesis of Vanilla planifolia Andrews. Revista Facultad Nacional de Agronomía, v.70, p.80238031, 2017. https://doi.org/10.15446/rfna.v70n1.61736

Donato, P. E. R.; Pires, A. J. V.; Donato, S. L. R.; Bonomo, P.; Silva, J. A.; Aquino, A. A. Morfometria e rendimento da palma forrageira 'Gigante' sob diferentes espaçamentos e doses de adubação orgânica. Revista Brasileira de Ciências Agrárias, v.9, p.151-158, 2014. https://doi.org/10.5039/agraria.v9ila3252

EMBRAPA - Empresa Brasileira de Pesquisa Agropecuária. Manual de métodos de análise de solo. 2.ed. Rio de Janeiro, Centro Nacional de Pesquisa de Solos, 1997. 212p.

Franck, N.; Muñoz, V.; Alfaro, F.; Arancibia, D.; Pérez-Quezada, J. Estimating the carbon assimilation of growing cactus pear cladodes through different methods. Acta Horticulturae, v.19, p.157-164, 2013. https://doi.org/10.17660/ActaHortic.2013.995.19

Grünwaldt, M. J.; Guevara, J. C.; Grünwaldt, E. G. Review of scientific and technical bibliography on the use of Opuntia spp. as forage and its animal validation. Journal of the Professional Association for Cactus Development, v.17, p.13-32, 2015.

Larcher, W. Ecofisiologia vegetal. São Carlos: Rima, 2000. 529p.

Masrahi, Y. S.; Al-Turki, T. A.; Sayed, O. H. Crassulacean acid metabolism permutation and survival of Caralluma species (Apocynaceae) in arid habitats. Ecologia Balkanica, v.4, p.63-71, 2012.

Nobel, P. S. Biologia ambiental. In: Barbera, G.; Inglese, P.; PimientaBarrios, E. P. (eds.). Agroecologia, cultivo e uso da palma forrageira. Roma: FAO/ João Pessoa: SEBRAE-PB, 2001. p.36-48. 
Pimienta-Barrios, E.; Zañudo-Hernández, J.; Muñoz-Urias, A.; Murguía, C. R. Ecophysiology of young stems (cladodes) of Opuntia ficusindica in wet and dry conditions. Gayana. Botanica, v.69, p.232-239, 2012. https://doi.org/10.4067/S0717-66432012000200002

Pimienta-Barrios, E.; Zañudo-Hernández, J.; Rosas-Espinoza, V. C.; Valenzuela-Tapia, A.; Nobel, P. S. Young daughter cladodes affect $\mathrm{CO}_{2}$ uptake by mother cladodes of Opuntia ficus-indica. Annals of Botany, v.95, p.363-369, 2005. https://doi.org/10.1093/aob/mci034

Romo-Campos, R.; Flores-Flores, J. L.; Flores, J.; Álvarez-Fuentes, G. Factores abióticos involucrados en la facilitación entre leñosas y suculentas en el altiplano mexicano. Botanical Sciences, v.91, p.319-333, 2013. https://doi.org/10.17129/botsci.11

Silva, J. A. da; Donato, S. L. R.; Donato, P. E. R.; Souza, E. dos S.; Padilha Júnior, M. C.; Silva Júnior, A. A. e. Yield and vegetative growth of cactus pear at different spacings and under chemical fertilizations. Revista Brasileira de Engenharia Agrícola e Ambiental, v.20, p.564-569, 2016. https://doi.org/10.1590/18071929/agriambi.v20n6p564-569
Strauss, A. J.; Krüger, G. H. J.; Strasser, R. J.; Heerden, P. D. R. van. Ranking of dark chilling tolerance in soybean genotypes probed by the chlorophyll a fluorescence transient O-J-I-P. Environmental and Experimental Botany, v.56, p.147-157, 2006. https://doi. org/10.1016/j.envexpbot.2005.01.011

Taiz, L.; Zeiger, E.; Moller, I. M.; Murphy, A. Fisiologia e desenvolvimento vegetal. 6.ed. Porto Alegre: Artmed, 2017. 858p.

Winter, K.; Lesch, M. Diurnal changes in chlorophyll a fluorescence and carotenoid composition in Opuntia ficus-indica, a CAM plant, and in three $\mathrm{C}_{3}$ species in Portugal during summer. Oecologia, v.91, p.505-510, 1992. https://doi.org/10.1007/BF00650323

Zañudo-Hernández, J.; Aranda, E. G. C.; Ramírez-Hernández, B. C.; Pimienta-Barrios, E.; Castillo-Cruz, I. Ecophysiological responses of Opuntia to water stress under various semi-arid environments. Journal of the Professional Association for Cactus Development, v.12, p.20-36, 2010. 